\title{
Application of Mind Mapping Method in College English Vocabulary Teaching
}

\author{
Gehong Liu \\ School of Applied Technology, The University of Science and Technology Liaoning, Anshan, China \\ Email: LGHong@126.com
}

Received 3 May 2016; accepted 3 June 2016; published 7 June 2016

Copyright (C) 2016 by author and Scientific Research Publishing Inc.

This work is licensed under the Creative Commons Attribution International License (CC BY).

http://creativecommons.org/licenses/by/4.0/

cc) (i)

\begin{abstract}
With increasingly deepening of exchange and cooperation between China and the world, nowadays, the society has higher requirements for college students' English ability. This article discusses the application of mind mapping in college English vocabulary teaching, thinks that mind mapping can promote teaching efficiency and improve students' practical application ability, cultivate students' good thinking habits, aims at application of mind mapping in college English vocabulary teaching, puts forward three effective ways, namely teachers formulate mind mapping, encourages students to make mind mapping, and carries out network teaching. This article aims at making useful contributions for promoting the improvement of teaching quality of college English teaching at present through effective exploration and discussion.
\end{abstract}

\section{Keywords}

Mind Mapping, College English, Vocabulary Teaching, Application

\section{Interpretation of Related Concepts of Mind Mapping and College English Vocabulary}

\subsection{Mind Mapping}

The so-called mind mapping is also called mind map. It is a graphic thinking tool used to represent radioactive thinking. Mind mapping has simple and effective characteristics. As a thinking tool with revolutionary nature, it uses the way of excellent picture and its accompanying essay to connect principal parts at all levels and shows words and expressions and vocabularies with membership function through hierarchical relationship and finding new tree-shaped relationship. Mind mapping follows ways of thinking such as divergent thinking and centralized thinking on framework and carries out divergent representation for words and expressions and vocabularies of 
peripheral themes related to central word. Looking from physiological angle, this representation can fully mobilize joint collaboration of left brain thinking and right brain thinking to understand and remember a certain kind of knowledge. This method of memory that centers on the central point can reframe, reclassify and recreate knowledge in learners' mind, make new knowledge integrate with old knowledge in learners' mind to achieve the goal of improving learning efficiency. With continuous development of relevant theories, application of mind mapping in language teaching begins to be acknowledged by educational circles. In terms of nature of fragmentation of language teaching, using mind mapping to systematically sort fragmented language and words can help to improve students’ learning efficiency and enhance students’ language competence. Meanwhile, mind mapping can exercise students' mind in the application process, which helps students to achieve the purpose of jointly developing the left and right brain, improving thinking ability of students' mind as well as enhancing their learning efficiency (Farrand, 2012).

\subsection{College English Vocabulary Teaching}

Different from English language teaching in junior middle school stage, college English aims at improving students' comprehensive abilities of language application. In terms of employment market at present, when recruiting talents, many companies have requirements for English competence of college graduate. The larger the scale of company, the higher the level and salary will be. It tends to have higher requirements for students' English competence.

In the stage of college English, English grammar teaching has been no longer the key point of college English teaching. College English teaching requires students to master more vocabularies and use English to carry out richer and clearer self-expression. Therefore, vocabulary teaching becomes the key point of college English teaching. On literal expression and language use, English is entirely different from Chinese. So although through lengthy English language learning in junior middle school stage, quite a number of students still lack experience in English learning and cannot use English to better express their opinions, let alone using English to communicate with foreigners. Analyzing these problems and barriers, it is found that the lack of vocabulary is the main reason. Therefore, in teaching process of college English, it has very important significance and value on improving students' comprehensive abilities and English competence through implementing effective vocabulary teaching for students, using appropriate teaching methods, enlightening students to master more English vocabulary.

\section{Necessity of Mind Mapping in College English Vocabulary Teaching}

\subsection{Promote Teaching Efficiency}

The application of mind mapping in college English vocabulary teaching can effectively improve teaching efficiency. The improvement of teaching efficiency is embodied on enhancement of teachers' classroom efficiency. In the past classroom teaching, in order to make students master an English word, teachers need to give students quite a long period to remember pronunciation and style of writing of words. In this process, the vast majority of teachers adopt the method of rote memory. That is to say, they require students to master new vocabularies learned in class through rote memory in fixed time. The deficiency of this method is that English language has conflicts with students' abstraction and finiteness of students' memory ability. It is found from classroom experience in the past that the number of English words mastered and remembered by each student in fixed period of time is finite (Rumelhart \& Ortony, 2012). English word serves as organic component in English language framework. The relationship between words is close. But mechanical teaching method separates interrelation between English words and increases the burden on students' learning imperceptibly. If teachers introduce teaching method of mind mapping in class, guide students to look English words as a unified whole and help students to draw inferences about other cases from one instance and remember a number of different words in the same thinking process, it can greatly improve classroom teaching efficiency. At the same time, application of mind mapping in college English vocabulary teaching can reduce the heavy burdens of teachers. In the past mechanical English vocabulary teaching, teachers always need to explain English words one by one. In this link, teachers consume a lot of energy in speaking. The teaching effect is limited and it gets half the result with twice the effort. With application of mind mapping in English language teaching, English teachers can use this method to ease the burden of their own in classroom and achieve the desired effect of half the work with double results. 


\subsection{Improve Students' Practical Application Ability}

The ultimate goal of English teaching is to let students put it into practice. The teaching method of mind mapping can let students learn divergent thinking in English learning process, recombine and integrate English materials in their mind. When they need to apply English on the spot, their mind will automatically take relevant mind map and use language in mind mapping framework to describe their thoughts. In reality, this process is to improve students' language applying ability. We can know from the past research experience that the improvement of students' practical application ability comes from improvement of their thinking capacity. In the past English language vocabulary teaching, students mechanically master fragmented English language. In this process, they lack their own thinking and haven't experience in English learning. Under the influence of "duckstuffing” type of teaching, students tend to finish rote memory of English vocabularies and don't have the consciousness of practically applying English vocabulary. As a matter of fact, this is the real reason why college students' ability of using English at present is inadequate (Zou, 2013).

The reality is that in current education system of our country, special attention is paid to English learning in the basic teaching stage. Before entering colleges, students have learned English for 10 years or longer. In terms of students' accumulation in current English, the details are quite profound. Students only lack the ability to recombine the existing linguistic data and apply them to English conversation. The application of mind mapping can lead students to improve thinking ability then achieve the purpose of enhancing students' practical application ability.

\subsection{Cultivate Students' Good Thinking Habits and Promote Students' Comprehensive Abilities}

With deep development of quality-oriented education, it has become the key of the current quality-oriented education to improve students' comprehensive abilities, especially promote students' thinking ability and extend students' practical ability. Applying mind mapping method in college English vocabulary teaching can cultivate students to develop good learning habits and improve students' comprehensive abilities.

In the 21st century, the market competition of talents is the competition on the basis of knowledge and ability. In the competition process, only those students who have good thinking habits and truly have the ability to correctly deal with affairs can occupy active position in social competition and achieve success in life. The mind mapping method can also exist in English classroom teaching. In reality, we can effectively exercise students' thinking ability and mind and guide students to use divergent thinking to treat and solve problems (Zou \& Yan, 2012).

The means that mind mapping method teaches students to solve problems is only the external expression that it produces positive guidance on students' thinking ability. What's more, looking from physiological angle, the mind mapping method can activate joint thinking and mutual cooperation of left and right brains to improve students' intelligence. Looking from the perspective of physiology, the thinking ability of human is endowed by the brain. The active degree of thinking of human brain and speed of brain to deal with problems directly decide intelligence quotient of a person. People who often carry out thinking exercise with good cooperation of left and right brains will always acquire higher level in professional title appraisal.

\section{Several Paths for Mind Mapping to Apply in College English Vocabulary Teaching}

\subsection{Teachers Make Mind Map and Teach Students to Learn}

Analyzing the production of mind mapping, we can find that although it is an external graphics expression, mind map contains profound knowledge deposits. Therefore, it is obviously unpractical to only rely on students to independently finish mind mapping. Teachers shall undertake the main task of making mind mapping and take the production of mind mapping as contents of less preparation seriously. In concrete preparation, they shall adopt flexible and careful thinking to make relevant diagrams, strive to give consideration to preciseness of knowledge and richness of contents to attract students' learning interest.

To be specific, in the process of making mind map, teachers shall explicitly note logic relationship between vocabularies and do not mislead students and make students misunderstand.

For example, in the process of graph production related to adjective words, special attention should be paid to 
distinction of logic relationship between words and expressions that form mind map. Centering on the central words of adjective words, teachers shall list a few words related to it. But analyzing all adjective words, we find that it lacks close logic relationship between vocabularies. Therefore, when forming mind map, these vocabularies shall not be placed in the same field for students to understand. We should put vocabularies with different natures and different emotional tendencies in mind mapping projects with different shapes, use intuitive approach to help students to distinguish and understand different classification of adjective words. In the process of making mind map, teachers should attach importance to making the mind map easy to understand. Students have different learning background from teachers (Zou, 2010). Due to the different learning background, teachers and students have completely different knowledge possession volume and English deposits. Generally speaking, in these aspects, students' performance is not good as English teachers. Teachers shall take the current situation into full consideration. When making mind map, they shall consider students' receptivity and make the logic concise as far as possible and easy for students to understand. It should be realized that the most direct purpose to apply mind mapping is to help students to improve efficiency of English vocabulary learning, exercise students' thinking ability. It is only a secondary product in the process of learning English. They shall not complicatedly set mind mapping in order to simply emphasize exercising students’ thinking ability.

\subsection{Encourage Students to Make Mind Map}

As main part of English classroom teaching, students play a decisive role in producing teaching effects. In the process of teaching vocabulary in college English class, such as teaching method of mind mapping, the ultimate purpose is to improve students' English language application ability and enhance students' comprehensive abilities. If teachers blindly emphasize “duck-stuffing” type of teaching on students and guide students to use mind map made by teachers, it will make students fall into cycle of rigidity of thinking, have the thought of dependency, instead of actively using their minds to think problems related to mind map. This kind of wrong tendency will lead to the fact that the efficiency of students in learning English vocabulary becomes low. Meanwhile, it will also confine students' thoughts and make it stay at a lower dimension. The application of teaching method of mind mapping has not been able to finally achieve the purpose of greatly improving students' comprehensive abilities. Aiming at this situation, teachers shall base on making mind map, guide and encourage students to make mind map.

For example, when teachers make mind map related to verbs, they can consider giving students a simple demonstration of mind map production of verbs within small range and leave homework for students to make mind maps of the rest of verbs in spare time. Teachers can also spare time in class to comment on and appraise homework finished by students, correct mistakes made by students in the process of mind map production and guide students to develop correct and good thinking methods.

The process of English learning is a process of completing something independently. Even though teachers have the best method, finally it also needs students to actively put it into practice. Therefore, in the process of teaching, teachers shall guide students to independently complete the production of mind map. That is to say, guide students to actively think and learn English, change the past "duck-stuffing” type of teaching into quality-oriented education and guide students to learn actively. This kind of method often can rapidly improve students' quality of learning.

\subsection{Implement Network Teaching}

In the network age with sharing as the characteristics, teachers and students cannot only stay at the stage of working behind closed doors and completely depend on themselves to independently make mind map to support the learning of college English vocabulary. In order to fulfill the task of English teaching more quickly and achieve the purpose of improving students' English level, teachers shall consider introducing internet tools into teaching.

With continuous popularization of mind map in college English vocabulary teaching, English teachers and students in colleges and universities across the country are exploring to use mind map to teach and learn English vocabulary. In order to realize maximum using of resources, colleges can consider establishing a platform of information interaction on the internet and upload mind map made by them to the internet. In the process of communicating with each other, reduce time cost of each college wasted in repeating making mind map, in order to achieve the ultimate purpose of improving teaching and learning efficiency. 
For example, colleges can consider basing on teaching association of application and adopt the method of opening English forum. English teachers in each college upload mind maps made by them and students to relevant forums and share information through the medium of forum. This method can save time and improve efficiency.

However, we shall realize that the establishment of sharing platform in network age does not mean it is totally free. The production of mind map needs to cost a lot of time and energy. As a kind of fruit of labor of producers, the producer of mind map has the right to acquire certain economic returns via purchase of mind map. Therefore, for those people who have not ability or energy to make mind maps, if they want to obtain the right of using mind maps made by others, it is necessary for them to pay the originator. The establishment of payment mechanism needs more in-depth discussion.

\section{Conclusion}

The application of mind mapping method in college English vocabulary teaching can improve students' learning interest, enhance their English proficiency, exercise their thinking and improve their comprehensive abilities. Although mind mapping needs students and teachers to make by spending a lot of time and energy, the achievement of production can benefit students and improve students' competitiveness in employment market. Therefore, as main force of mind mapping production, English teachers in colleges shall actively take on the job to make mind mapping, try every means to make the logic of mind mapping production smooth, terse and concise, in order to help students to learn English more quickly with high efficiency. College students shall have a clear and profound understanding on teaching method of mind mapping as well as actively coordinate with teachers' work.

\section{References}

Farrand, P. (2012). The Efficacy of the Mind Mapping Study Technique. Medical Education, 36, 426-431.

Rumelhart, D. E., \& Ortony, A. (2012). The Representation of knowledge in Memory in Schooling and the Acquisition of Knowledge (pp. 169-175). Hilsdale, NJ: LAWRENCE Erlbaum Associates.

Zou, A. M. (2013). Discussion on College English Vocabulary Teaching. Foreign Language World, No. 1, 29-33.

Zou, M. Q., \& Yan, X. H. (2012). Application of Mind Mapping in College English Teaching. Journal of Changchun Normal University, No. 5, 37-39.

Zou, J. (2010). Use Mind Mapping to Change Way of English Learning. Journal of Chongqing University of Science and Technology, No. 8, 44-48. 